\title{
PRESCRIBING OF DRUGS FOR THE TREATMENT OF MIGRAINE WITH SPECIFIC EM- PHASIS ON SUMATRIPTAN
}

\author{
Ilse Truter
}

DCom, BPham, MSc, PhD

Registered Pharmacist, Associate Professor in Pharmacy and Head of Pharmacy Practice, Department of Phamacy, University of Port Elizabeth

Corresponding author: ilse.truter@upe.ac.za

\section{Theunis $\mathbf{J}$ van $\mathbf{W}$ Kotze}

DSc

Director, TheoData cc

Keywords: migraine; sumatriptan; prescribing patterns; drug utilisation; pharmacoepidemiology

\section{ABSTRACT}

Migraine affects between $5-15 \%$ of males and $13,5-31 \%$ of females in South Africa. Little is known about the prescribing patterns of anti-migraine drugs in South Africa. The aim of the study was to investigate the prescribing of drugs for the treatment of migraine (ATC Group N02C), with specific emphasis on sumatriptan, in a primary care patient population in South Africa, making use of a computerised prescription database. A total of 3011 products for the treatment of migraine at a cost of R451 559 were prescribed to 578 patients in the study over a period of one year (1996) since sumatriptan was the only triptan available in South Africa in 1996. The average age of patients was $48,40(S D=14,19)$ years, with $74,57 \%$ of patients between 20 and 59 years of age. Approximately $80 \%$ of patients were females. Female patients were prescribed $81,53 \%$ of the products. Most drugs (67,55\%) were for the prophylaxis of migraine, of which clonidine and flunarizine were the most frequently prescribed. Of the drugs prescribed specifically for the management of migraine, sumatriptan (575 prescriptions to 103 patients) was the most frequently prescribed, followed by 400 prescriptions for ergotamine. Tablets were the preferred dosage form. Since migraine affects primarily the economically active sector of the community and its treatment is relatively expensive, pharmacists have an important role to play in managing and counselling migraine sufferers.

\section{OPSOMMING}

Migraine affekteer tussen 5-15\% van mans en 13,5-31\% van vroue in Suid-Afrika. Min inligting is beskikbaar oor die voorskryfpatrone van middels teen migraine in Suid-Afrika. Die doel van die studie was om die voorskrywing van middels vir die behandeling van migraine (ATC Groep N02C) in 'n primêre sorg-pasiëntpopulasie te ondersoek, met spesifieke klem op sumatriptan, deur gebruik te maak van 'n gerekenariseerde voorskrif-databasis. ' $n$ Totaal van 3011 produkte vir die behandeling van migraine teen 'n koste van $R 451559$ is aan 578 pasiënte in die studie oor ' $n$ tydperk van een jaar (1996) voorgeskryf aangesien sumatriptan die enigste triptan was wat beskikbaar was in 1996. Die gemiddelde ouderdom van die pasiënte was $48,40(S D=14,19)$ jaar, met $74,57 \%$ van die pasiënte tussen 20 en 59 jaar oud. Ongeveer $80 \%$ van die pasiënte was vroue. Vroulike pasiënte het $81,53 \%$ van die voorgeskrewe produkte ontvang. Die meeste middels (67,55\%) was vir die voorkoming van migraine, waarvan klonidien en flunarisien die meeste voorgeskryf is. Van die middels spesifiek vir die behandeling van migraine, was sumatriptan (575 voorskrifte aan 103 pasiënte) die meeste voorgeskryf, gevolg deur 400 voorskrifte vir ergotamien. Tablette was die gewildste doseervorm. Aangesien migraine hoofsaaklik die ekonomies aktiewe sektor van die gemeenskap beïnvloed en die behandeling relatief duur is, het aptekers ' $n$ belangrike rol om te vervul in die bestuur en konsultering van migrainelyers. 


\section{BACKGROUND TO THE STUDY}

Headache disorders are extremely prevalent and represent a major health problem which merits increased attention (Rasmussen, Jensen, Schroll \& Olesen, 1991:1147; Rasmussen, Jensen \& Olesen, 1992:443). Usually they are mild or infrequent, but when they are severe or frequent they cause considerable suffering as well as decreased or abolished working capacity (Rasmussen et al. 1991:1147). In a study conducted in Denmark on a random population of 25- to 64-year-old men and women, the lifetime prevalence of headache (anybody with any form of headache), migraine and tension-type headache was $93 \%, 8 \%$ and $69 \%$ in men, and $99 \%, 25 \%$ and $88 \%$ in women, respectively (Rasmussen et al. 1991:1147). In the migraine group, nearly all stated that the pain impaired or abolished their working capacity or other activities (Rasmussen et al. 1991:1147; Rasmussen et al. 1992:443). In Belgium, migraine affects up to $5,8 \%$ of the population at some time in their life, with a gender ratio of $86 \%$ in women to $14 \%$ in men (Schoenen, Bulcke, Caekebeke, Dehaene, De Keyser, Hildebrand, Joffroy, Laloux, Louis, Monseu, Pierre, Vanderlinden, Sautois \& Vandenberghe, 1994:55). Research in South Africa has shown that migraine affects between $5 \%$ and $15 \%$ of males and $13,5 \%$ and $31 \%$ of females (Turner, 1996:2).

Migraine is defined as a headache that lasts four to 72 hours, is throbbing, is moderate to severe in intensity, is unilateral, becomes worse with exertion, and is associated with nausea, vomiting, or sensitivity to light, sound or smell. Only three or four of the above criteria must be present for accurate diagnosis (Merck Manual of Diagnosis and Therapy, 1999:1376). Migraine may occur at any age but usually begins between the ages of 10 and 40 years, more often in women than in men (Merck Manual of Diagnosis and Therapy, 1999:1376). Headaches often partially or completely remit after the age of 50 years (Merck Manual of Diagnosis and Therapy, 1999:1376). The mean frequency of migraine attacks is 1,5 attacks per month, but it is important to stress that at least $10 \%$ of patients suffering from migraine will have one attack per week (Smuts, 2003:29). Migraine is therefore a major reason for time lost from work and resulting medical expenses (Smuts, 2003:29), and as such a disorder of economic importance.

Various drug products are available on the South Afri- can market for the prevention and treatment of migraine. Therapies for migraine are either prophylactic, such as beta-blockers, calcium channel blockers, pizotifen and methysergide, or acute, such as ergot derivatives, analgesics, non-steroidal anti-inflammatory agents or narcotics very often associated with antiemetics (Schoenen et al. 1994:55). The triptans are some of the newer agents that are specifically indicated for the treatment of acute attacks of migraine. Four triptans are registered for use in South Africa, namely sumatriptan $\left(\right.$ Imigran $\left.^{\circledR}\right)$, rizatriptan (Maxalt $\left.{ }^{\circledR}\right)$, naratriptan $\left(\right.$ Naramig $\left.^{\circledR}\right)$ and zolmitriptan $\left(\right.$ Zomig $\left.^{\circledR}\right)$. Only one of these active ingredients, namely sumatriptan (Imigran $\left.{ }^{\circledR}\right)$, was available on the South African market in 1996 (SAMF, 1997; MIMS, 1997). Consequently the findings of this study provides important baseline information on triptan prescription.

Sumatriptan, a selective serotonin agonist agent, has been described as a welcome addition to the physician's arsenal (Gaist, Hallas, Sindrup \& Gram, 1996:161). Sumatriptan is specifically indicated for the treatment of acute attacks of migraine but can also be used for the treatment of cluster headaches (Gaist et al. 1996:161; MeReC Bulletin, 1992:29). It may be administered orally or by subcutaneous injection, with an onset of action within 10 minutes (subcutaneous) and 30 minutes (oral) (SAMF, 1997). It is generally recommended not to exceed a maximum repeated use of three $100 \mathrm{mg}$ tablets or two subcutaneous injections of $6 \mathrm{mg}$ daily, if the attack recurs within 24 hours (Gaist et al. 1996:161). The different strengths and package sizes in which sumatriptan was available at the time of the study in South Africa were:

- $6 \mathrm{mg} / 5 \mathrm{ml}$ starter pack;

- refill pack;

- $50 \mathrm{mg}(2)$ tablets;

- $50 \mathrm{mg}(6)$ tablets; and

- $100 \mathrm{mg}(4)$ tablets.

Adverse drug reactions attributed to sumatriptan in the postmarketing period include acute myocardial infarction, depression and skin reactions (Ottervanger, Valkenburg, Grobbee \& Stricker, 1996:353). Furthermore, since the marketing of the drug, several patients have been observed who developed an increase in the frequency of migraine attacks with consequent dependence and misuse (Ottervanger et al. 1996:353). The potential for overuse or abuse of sumatriptan has 
therefore been investigated by several researchers (Gaist et al. 1996; Ottervanger et al. 1996).

Pharmacoepidemiology is defined as the application of epidemiologic reasoning, methods and knowledge to the study of the uses and effects (beneficial and adverse) of drugs in human populations (Porta, Hartzema \& Tilson, 1998:2). Pharmacoepidemiology therefore aims to describe, explain, control and predict the uses and effects of pharmacologic treatments in a defined time, space and population. Its core lies at the intersection of two subspecialities, namely clinical pharmacology and clinical epidemiology. It is a useful and appropriate approach to study drug prescribing and usage, and to relate it to the different disease states for which drugs are indicated.

Little is known about the extent and type of medicine and health service utilisation of patients suffering from migraine in South Africa. Information on the prescribing patterns of sumatriptan is also lacking. Furthermore, because the triptans are expensive drugs and because migraine affects primarily the economically active sector of the population, it is important from an economic and cost point of view to analyse the drug treatment of migraine. The primary aim of the study was therefore to investigate the prescribing of drugs for the treatment of migraine (ATC Group N02C), with specific emphasis on sumatriptan, in a well-defined primary care patient population in South Africa, making use of a computerised prescription database, in order to comment on usage patterns and cost. Since sumatriptan is specific in its action and is used exclusively for the treatment of migraine, it was decided to focus on the prescribing patterns of sumatriptan in more detail.

\section{SUBJECTS AND METHODS}

Computerised medication records were obtained from a national pharmaceutical benefit management (PBM) company that serves various medical aid schemes in South Africa and is one of the largest PBMs in South Africa. Prescription data of 578 patients who received one or more drugs for the treatment of migraine (ATC Group N02C) during one year (1 January 1996 to 31 December 1996) were retrospectively analysed. Since the 1996 data were relatively old, additional reference to the results of a similar study on 2002 data from a different (smaller) South African PBM will be made in the results section. It is, however, not a comparative study since further analyses must still be conducted on the 2002 data and the two datasets are not directly comparable in all respects. The ATC Classification System (Anatomical Therapeutic Chemical (ATC) classification index with Defined Daily Doses (DDDs), 1999), the South African Medicines Formulary (SAMF, 1997) and MIMS (1997) were used to identify drugs and to classify drugs into their main therapeutic groups. Descriptive statistics were used in the data analysis. The Pearson chi-square test was applied to frequency data to compare the distributions of the two genders where appropriate. All costs in the study are indicated in South African Rand (R).

Each medication record contained information on the date of birth and gender of the patient, with a unique number to identify each patient. This number was randomly allocated by the organisation providing the data to ensure patient confidentiality. Furthermore, the date of the prescription, detailed information on the dispensed drug (name, package size, formulation and quantity), price and various reimbursement variables were also recorded. The indication for treatment was, however, not registered. Limitations of the study were therefore that the data were relatively old (1996), no diagnoses, medical history (except for the drugs prescribed) or information on the lifestyle habits of patients (for example, smoking and diet) were available. It is therefore possible that patients who suffered from mild or low frequency migraine that did not require the more aggressive treatment for migraine may not be included in this patient sample.

\section{RESULTS AND DISCUSSION}

\section{Prescribing and cost of drugs in ATC Group N02C}

A total of 3011 products for the treatment of migraine at a cost of R451 559 were prescribed to the 578 patients in the study over a period of one year. Patients were therefore prescribed an average of $5,21(S D=5,02)$ products for migraine over the year. Half of the patients (292 patients) received three or less products for migraine during the year. Female patients received an average of $5,40(S D=5,11$, minimum $=1$, maximum $=$ 49) products over the year, compared to $4,52(\mathrm{SD}=$ 4,71 , minimum $=1$, maximum $=31$ ) for male patients. 
Approximately $80 \%$ of the patients in the study were females, and female patients were prescribed $81,53 \%$ of the products. The average age of patients was 48,40 $(S D=14,19)$ years, with $74,57 \%$ of patients between 20 and 59 years of age.

The prescribing frequency and cost of the different drugs for female and male patients are given in Table 1. Most drugs $(67,55 \%)$ were for the prophylaxis of migraine, of which clonidine and flunarizine were the most frequently prescribed. Prescribing differences between female and male patients were observed for the different drugs. Clonidine was more frequently prescribed to female patients, and flunarizine more frequently to male patients. Clonidine was relatively inexpensive, accounting on average for $32,22 \%$ of the prescribing volume but for only $21,37 \%$ of prescribing cost. The opposite was true for sumatriptan, which accounted for $19,10 \%$ of prescribing volume but for $38,65 \%$ of prescribing cost. Tablets were the preferred dosage form (accounting for $64,66 \%$ of all prescriptions), followed by capsules $(31,78 \%)$, suppositories $(2,46 \%)$ and injections $(1,10 \%)$.

Of the drugs prescribed specifically for the management of migraine, sumatriptan (575 prescriptions to 103 patients) was the most frequently prescribed. Since the focus of this study is on the prescribing of sumatriptan, the rest of the manuscript will discuss the prescribing of sumatriptan.

\section{Age and gender distribution of patients prescribed sumatriptan}

A total of 2198 drug items (all therapeutic groups) were prescribed to the 103 patients receiving sumatriptan. Sumatriptan accounted for $26,16 \%$ of all the prescriptions to these patients, and for $47,37 \%$ of the prescribing cost. This again gives an indication that sumatriptan is relatively expensive when compared with the other drugs that were prescribed.

The age and gender distribution of the 103 patients who received one or more prescriptions for sumatriptan during the study period is given in Table 2 . The majority of patients $(80,58 \%)$ were females, which is in agreement with literature findings (Schoenen et al. 1994:57; Van Schoor, 1999:4). In a study on the use of sumatriptan in Denmark in 1994 and 1995, a female to male one year period prevalence ratio of 3,8:1 was found (Gaist, Andersen, Aarup, Hallas \& Freng Gram, 1997:433). Female patients furthermore received proportionately more medicine items ( $89,85 \%$ of the 2198 products), than male patients $(10,15 \%)$. Three quarters of the patients $(75,73 \%)$ were between 30 and 59 years of age. The Pearson chi-square test was used to detect differences between female and male patients $\left(\chi^{2}=4,40\right.$; d.f. $=2 ; p<0,5)$. Differences were observed in the frequency distributions. There were proportionately more male patients in the younger age groups.

The average age of patients receiving sumatriptan was $41,99(\mathrm{SD}=11,53)$ years. Patients receiving sumatriptan were therefore on average younger than all the patients who received drugs for migraine $(41,99$ years compared to 48,40 years for all patients). The average age of female patients who were prescribed sumatriptan was 43,48 years $(S D=10,85$ years; median $=44$ years; minimum age $=22$ years; maximum age $=65$ years). The average age of male patients was 35,80 years (SD $=12,50$ years; median $=37,50$ years; minimum age $=$ 10 years; maximum age $=56$ years). The results of this study are therefore also in agreement with another study on sumatriptan use in Denmark in 1992 to 1994 , in which $78 \%$ of the users were females and the median age of users was 43 years (interquartile range 35 to 50 years) (Gaist et al. 1996:162). It can therefore be stated that young to middle-aged women are prescribed sumatriptan more often than other groups of people.

Sumatriptan is not indicated for patients over 65 years, or for patients under the age of 18 years (MIMS, 1997). Only one patient fell outside these age limits, namely a 10-year-old boy who received six prescriptions for sumatriptan over the one-year period in a dose of 50 $\mathrm{mg}$.

\section{Dosage forms in which sumatriptan was prescribed}

The 103 patients received a total of 575 prescriptions for sumatriptan during the year. The dosage forms in which sumatriptan was prescribed to female and male patients are illustrated in Table 3. Sumatriptan nasal spray was not yet available on the South African market at the time of the study. The $100 \mathrm{mg}$ dosage form was the most popular and accounted for $45,22 \%$ of all sumatriptan prescriptions. Tablets accounted for $94,26 \%$ 


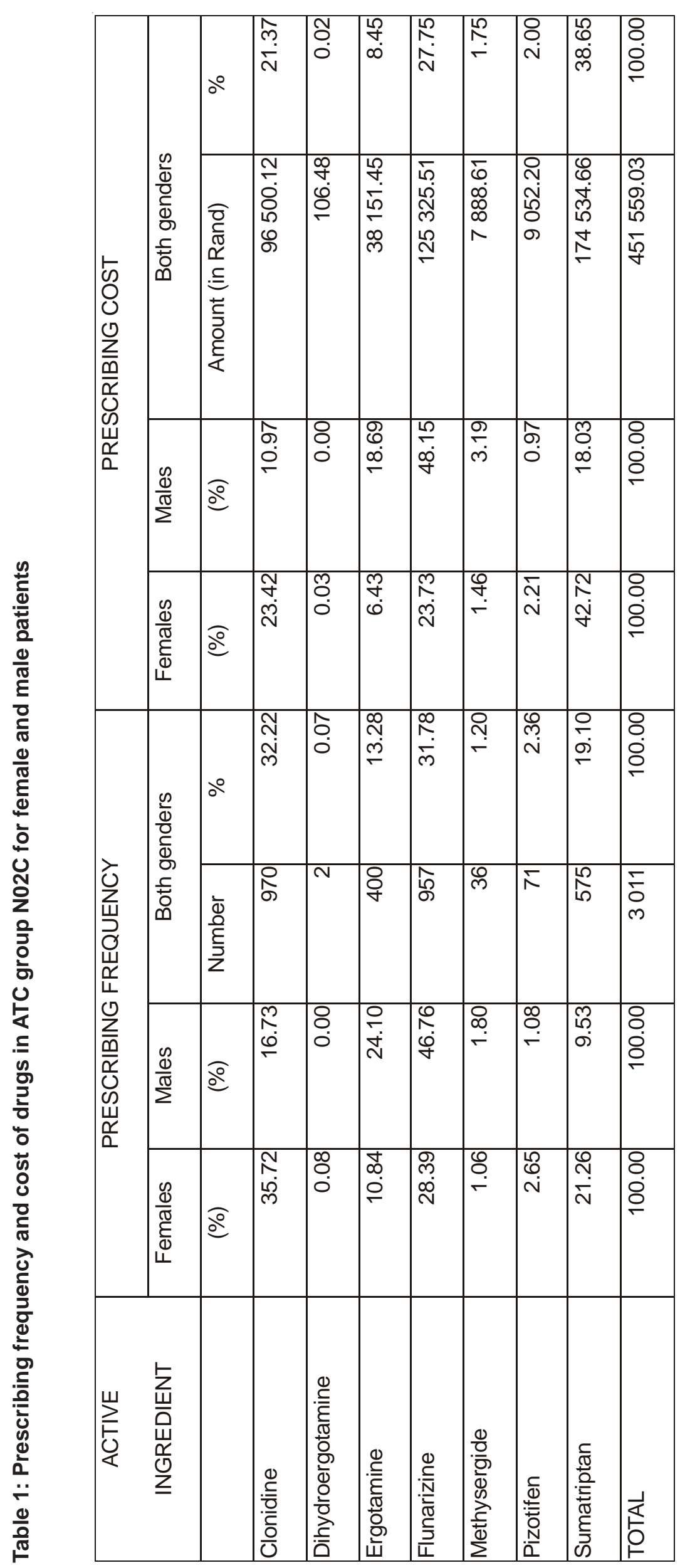


Table 2: Age and gender distribution of patients receiving sumatriptan *

\begin{tabular}{|l|c|c|c|c|}
\hline \multirow{2}{*}{$\begin{array}{c}\text { AGE GROUP } \\
\text { (in years) }\end{array}$} & \multirow{2}{*}{$\begin{array}{c}\text { \% FEMALES } \\
(\mathrm{n}=83)\end{array}$} & \multirow{2}{*}{$\begin{array}{c}\text { \% MALES } \\
(\mathrm{n}=20)\end{array}$} & \multicolumn{2}{c|}{ BOTH GENDERS } \\
\cline { 4 - 5 } & & & NUMBER & $\%$ \\
\hline$<30$ & 14,45 & 35,00 & 19 & 18,44 \\
\hline $30-39$ & 21,69 & 25,00 & 23 & 22,33 \\
\hline $40-49$ & 28,92 & 25,00 & 29 & 28,16 \\
\hline$\geq 50$ & 34,94 & 15,00 & 29 & 31,07 \\
\hline TOTAL & 100,00 & 100,00 & 103 & 100,00 \\
\hline
\end{tabular}

${ }^{*} \chi^{2}{ }_{(2)}=4,40 ; p<0,5$ (after collapsing the first two rows in the table).

Table 3: Dosage forms in which sumatriptan was prescribed

\begin{tabular}{|l|c|c|c|c|}
\hline \multicolumn{1}{|c|}{$\begin{array}{c}\text { DOSAGE FORM AND } \\
\text { PACKAGE SIZE }\end{array}$} & \multicolumn{4}{c|}{ NUMBER PRESCRIBED } \\
\cline { 2 - 5 } & FEMALES & MALES & BOTH GENDERS & $\%$ \\
\hline $6 \mathrm{mg} / 5 \mathrm{ml}$ starter pack & 13 & 0 & 13 & 2,26 \\
\hline Refill & 20 & 0 & 20 & 3,48 \\
\hline $50 \mathrm{mg} \mathrm{(2)} \mathrm{tablets}$ & 110 & 13 & 123 & 21,39 \\
\hline $50 \mathrm{mg} \mathrm{(6)}$ tablets & 141 & 18 & 159 & 27,65 \\
\hline $100 \mathrm{mg}(4)$ tablets & 238 & 22 & 260 & 45,22 \\
\hline TOTAL & 522 & 53 & 575 & 100,00 \\
\hline
\end{tabular}

of all sumatriptan prescriptions. In the study by Gaist and others (1997:430) on the use of sumatriptan in Denmark in 1994 and 1995, tablets accounted for $92 \%$ of the total sumatriptan consumption.

\section{Prescribing frequency of sumatriptan}

The frequency distribution of sumatriptan prescriptions for the different age and gender groups is given in Table 4. The Pearson chi-square technique was again used to investigate prescribing differences in respect of age and gender groups $\left(\chi^{2}=36,85 ;\right.$ d.f. $\left.=3 ; p<0,0001\right)$. Prescribing differences were observed between female and male patients. Female patients, accounting for $80,58 \%$ of patients in the study, received $90,78 \%$ of the prescriptions for sumatriptan. Male patients received more sumatriptan prescriptions at younger ages.

Patients received an average of $5,58(S D=6,26)$ prescriptions for sumatriptan over the year. Female patients received an average of $6,29(S D=6,69)$ prescrip- tions, compared with only $2,65(\mathrm{SD}=2,48)$ sumatriptan prescriptions for male patients.

More than half of the patients $(54,37 \%)$ received one, two or three prescriptions for sumatriptan during the year (see Table 5). Eleven patients received more than twelve prescriptions per year, in other words, more than one prescription for sumatriptan per month. In the study on the use of sumatriptan in Denmark in 1994 to 1995, it was found that $41 \%$ of sumatriptan users presented only a single prescription for sumatriptan (Gaist et al. 1997:431). In the earlier (1992 to 1994) Danish study, $45 \%$ of the patients submitted only one prescription for sumatriptan (Gaist et al 1996:162).

The Lorenz curve of sumatriptan prescribing is given in Figure 1. The $x$-axis indicates various percentiles, and the $y$-axis indicates these percentiles' cumulated share of total sumatriptan drug prescribing (Hallas \& Nissen, 1994). From the curve, it can be seen that $10 \%$ 
of the patients were responsible for $51,72 \%$ of the total number of prescriptions for sumatriptan, and that $50 \%$ of patients were responsible for $93,22 \%$ of all sumatriptan prescriptions. Utilisation of sumatriptan in the 1992 to 1994 Danish study was also highly skewed, with the one percent and $10 \%$ heaviest users of sumatriptan responsible for $20 \%$ and $60 \%$ of total consumption, respectively (Gaist et al. 1996: 162).

Table 4: Frequency distribution of sumatriptan prescription for the different age and gender groups

\begin{tabular}{|c|c|c|c|c|c|c|c|}
\hline \multirow{2}{*}{$\begin{array}{l}\text { AGE GROUP } \\
\text { (IN YEARS) }\end{array}$} & \multicolumn{2}{|c|}{$\begin{array}{l}\text { PRESCRIBING } \\
\text { FREQUENCY * }\end{array}$} & \multicolumn{2}{|c|}{ BOTH GENDERS } & \multicolumn{3}{|c|}{$\begin{array}{l}\text { AVERAGE NUMBER (SD) OF } \\
\text { SUMATRIPTAN PRESCRIPTIONS ** }\end{array}$} \\
\hline & $\begin{array}{c}\text { FEMALES } \\
(\mathrm{n}=522)\end{array}$ & $\begin{array}{l}\text { MALES } \\
(\mathrm{n}=53)\end{array}$ & NUMBER & $\%$ & FEMALES & MALES & BOTH GENDERS \\
\hline$<30$ & 7,85 & 32,07 & 58 & 10,08 & $3,42(2,39)$ & $\begin{array}{l}2,43 \\
(2,15)\end{array}$ & $3,05(2,30)$ \\
\hline $30-39$ & 26,25 & 33,96 & 155 & 26,96 & $7,61(7,38)$ & $\begin{array}{c}3,60 \\
(4,22)\end{array}$ & $6,74(6,94)$ \\
\hline $40-49$ & 37,35 & 18,88 & 205 & 35,65 & $8,13(9,49)$ & $\begin{array}{c}2,00 \\
(0,71)\end{array}$ & $7,07(8,92)$ \\
\hline$\geq 50$ & 28,55 & 15,09 & 157 & 27,31 & $5,14(3,58)$ & $\begin{array}{c}2,67 \\
(2,08)\end{array}$ & $4,91(3,52)$ \\
\hline TOTAL & 100,00 & 100,00 & 575 & 100,00 & $6,29(6,69)$ & $\begin{array}{c}2,65 \\
(2,48)\end{array}$ & $5,58(6,26)$ \\
\hline
\end{tabular}

$$
\chi_{(3)}^{2}=36,85 ; p<0,0001 \text {. }
$$

** Standard deviations (SDs) are indicated in brackets.

Table 5: Number of prescriptions for sumatriptan per patient over the study period

\begin{tabular}{|l|c|c|c|c|}
\hline \multirow{2}{*}{$\begin{array}{c}\text { NUMBER OF } \\
\text { PRESCRIPTIONS }\end{array}$} & \multicolumn{4}{|c|}{ NUMBER OF PATIENTS } \\
\cline { 2 - 5 } & FEMALES & MALES & BOTH GENDERS & $\%$ \\
\hline 1 & 16 & 8 & 24 & 23,30 \\
\hline 2 & 14 & 6 & 20 & 19,42 \\
\hline 3 & 10 & 2 & 12 & 11,65 \\
\hline 4 & 6 & 0 & 6 & 5,83 \\
\hline 5 & 4 & 2 & 6 & 5,83 \\
\hline$\geq 6$ & 33 & 2 & 35 & 33,97 \\
\hline TOTAL & 83 & 20 & 103 & 100,00 \\
\hline
\end{tabular}




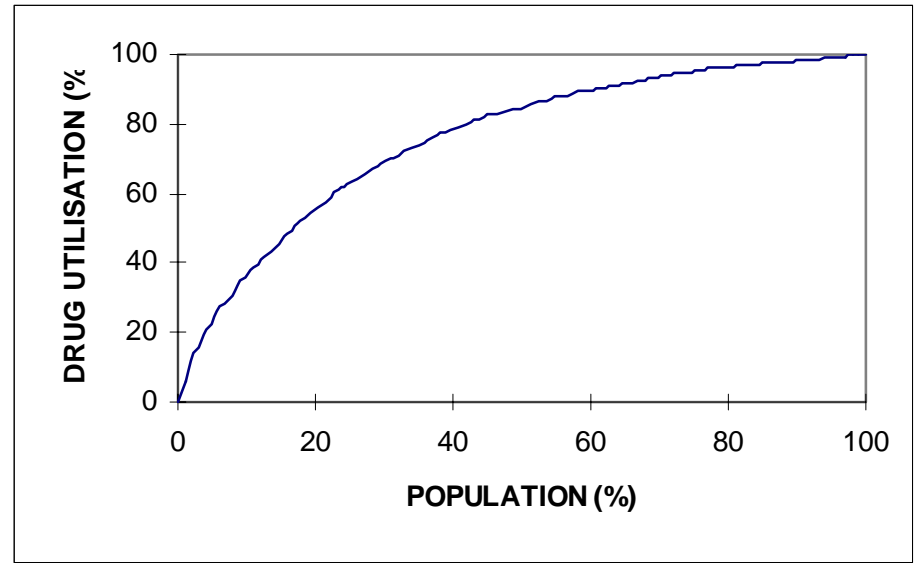

Figure 1: Lorenz curve of sumatriptan prescribing in the patient population

Table 6: Ten most often prescribed products (excluding sumatriptan)

\begin{tabular}{|c|c|c|c|c|c|c|}
\hline \multirow[t]{2}{*}{ RANK } & \multirow{2}{*}{$\begin{array}{c}\text { PROPRIETARY } \\
\text { NAME }\end{array}$} & \multirow{2}{*}{$\begin{array}{c}\text { ACTIVE } \\
\text { INGREDIENT(S) }\end{array}$} & \multicolumn{4}{|c|}{ PRESCRIBING FREQUENCY } \\
\hline & & & FEMALE & MALE & $\begin{array}{c}\text { BOTH } \\
\text { GENDERS }\end{array}$ & $\%$ \\
\hline 1 & Lentogesict & $\begin{array}{l}\text { Dextropropoxyphene } \\
\text {, paracetamol, } \\
\text { pemoline, L- } \\
\text { glutamine }\end{array}$ & 43 & 16 & 59 & 3,64 \\
\hline 2 & Stemetil" & Prochlorperazine & 41 & 0 & 41 & 2,53 \\
\hline 3 & Trepdine' & Amitriptyline & 38 & 0 & 38 & 2,34 \\
\hline 4 & Inderal' & Propranolol & 37 & 1 & 38 & 2,34 \\
\hline 5 & Sibelium' & Flunarizine & 21 & 10 & 31 & 1,91 \\
\hline 6 & Lanzor" & Lansoprazole & 26 & 2 & 28 & 1,73 \\
\hline 7 & Prepulsid" & Cisapride & 28 & 0 & 28 & 1,73 \\
\hline 8 & Efexor & Venlafaxine & 28 & 0 & 28 & 1,73 \\
\hline 9 & Premarin & $\begin{array}{l}\text { Conjugated } \\
\text { oestrogens }\end{array}$ & 28 & 0 & 28 & 1,73 \\
\hline 10 & Neoral' & Cyclosporine & 28 & 0 & 28 & 1,73 \\
\hline
\end{tabular}

* Calculated as a percentage of the total number of prescriptions, excluding sumatriptan ( $n=1623)$.

\section{Other drugs prescribed with sumatriptan}

A total of 1623 other products representing 219 different proprietary (trade) name products (excluding sumatriptan) were prescribed to the 103 patients during the course of the year. The ten most often prescribed products (excluding sumatriptan) are given in Table 6. The results of the 1992 to 1994 Danish study also indicated the use of strong analgesics, dextropropoxyphene and codeine with sumatriptan (Gaist et al. 1996:164).
Prescribing differences were detected in the prescribing of the different proprietary name products to female and male patients in the age groups under 30 years, 30 to 39 years, 40 to 49 years, and 50 years and older $\left(\chi^{2}=341,66 ; d f=3 ; p<0,0001\right)$. If all the products prescribed to the patient population are considered, it was interesting to observe that the average number of prescriptions per patient over the one year period was 21,24 (SD = 31,61). The average for female patients (average $=23,80 ; \mathrm{SD}=34,39$ ) was considerably higher 
than the average for male patients (average $=11,15$; $\mathrm{SD}=11,14)$.

\section{Cost of sumatriptan prescriptions}

A total of 2198 products at a cost of R368 427,39 were prescribed to the 103 patients. Sumatriptan accounted for $47,37 \%$ of the prescription cost, which is high if compared to the finding that sumatriptan accounted for only $26,16 \%$ of prescription volume. The average cost per prescription (all therapeutic groups) was R167,62 (SD $=\mathrm{R} 215,23)$. The average cost of a prescription for sumatriptan was $\mathrm{R} 303,54(\mathrm{SD}=\mathrm{R} 217,44)$, which is very high.

\section{Comparison with the results of a study on 2002 data}

The above results for 1996 are compared in a summarised manner with the results of another study conducted on the data of a different PBM in 2002 (see Table 7). As can be seen the results of the two studies differ. Sumatriptan was the only triptan available on the South African market during the 1996 study. After the introduction of the second generation triptans (naratriptan, rizatriptan and zolmitriptan), the prescribing frequency of the triptans increased to $26,89 \%$ in 2002 , compared to $19,10 \%$ for triptans (only sumatriptan) in the 1996 study. Further comparisons will be investigated. The 1996 study thus provides important baseline information on triptan prescription in South Africa.

\section{CONCLUSION AND RECOMMENDA- TIONS}

Analysis of medication consumption based on dispensing or reimbursement data has two limitations. Firstly, no information is available on non-compliance and, secondly, no information is available on drugs which are bought over-the-counter. Furthermore, this type of data also does not provide direct information on efficacy, clinical events or adverse reactions observed by consumers. Yet, despite the limitations, drug utilisation studies on prescription databases do provide a relatively inexpensive insight into the prescribing practices and cost of the various drug classes. Since little is known about the prescribing and use of drugs for the treat-

Table 7: Selected prescribing parameters of the 1996 and 2002 studies on anti-migraine preparations

\begin{tabular}{|l|c|c|}
\hline \multicolumn{1}{|c|}{ PRESCRIBING PARAMETER } & 1996 STUDY & 2002 STUDY \\
\hline Number of patients & 578 & 464 \\
\hline Average age of patients & $\begin{array}{c}48,40 \text { years } \\
(\mathrm{SD}=14,19 \text { years })\end{array}$ & $\begin{array}{c}42,36 \text { years } \\
(\mathrm{SD}=14,82 \text { years })\end{array}$ \\
\hline Percentage female patients & $78,72 \%$ & $63,58 \%$ \\
\hline $\begin{array}{l}\text { Average number of anti-migraine products } \\
\text { prescribed during the year }\end{array}$ & 5,21 & 2,90 \\
\hline $\begin{array}{l}\text { Percentage of patients receiving three or less anti- } \\
\text { migraine products during the year }\end{array}$ & $50,52 \%$ & $95,04 \%$ \\
\hline $\begin{array}{l}\text { Percentage of drugs for the prophylaxis of } \\
\text { migraine }\end{array}$ & $67,55 \%$ & $60,70 \%$ \\
\hline Percentage of prescriptions for sumatriptan & $19,10 \%$ & $6,69 \%$ \\
\hline $\begin{array}{l}\text { Percentage of prescriptions with tablets as } \\
\text { dosage form }\end{array}$ & $64,66 \%$ & $72,88 \%$ \\
\hline
\end{tabular}


ment of migraine in South Africa, the aim of the study was to investigate the prescribing of drugs for the treatment of migraine (ATC Group N02C), with specific emphasis on sumatriptan, in a well-defined primary care patient population in South Africa.

A total of 3011 products for the treatment of migraine at a cost of R451 559 were prescribed to the 578 patients in the study during 1996. The average age of patients was 48,40 years, with approximately $80 \%$ of patients being females. Most drugs (67,55\%) were for the prophylaxis of migraine, of which clonidine and flunarizine were the most frequently prescribed. Of the drugs prescribed specifically for the management of migraine, sumatriptan was the most frequently prescribed. The preliminary results of a study on 2002 data indicated that there was an increase in the prescribing frequency of the triptans after the introduction of the new second generation triptans on the South African market, and a slight decrease in the prescribing of products for migraine prophylaxis. These findings are currently being further investigated.

Sumatriptan is highly efficacious in aborting acute attacks of migraine. The average age of patients prescribed sumatriptan in the 1996 study was 41,99 years (younger than the total study population), with the majority of patients $(80,58 \%)$ also being females. Similar to other studies, the prescribing of sumatriptan in this study was skewed, with $10 \%$ of patients responsible for more than half of all sumatriptan prescriptions. Although it is not possible to prove overuse or abuse of sumatriptan in this study due to a lack of diagnosis or migraine attack rates, the overuse of sumatriptan can have important economic consequences. The results of a study conducted in the Netherlands during approximately the same time found that a small group of patients (four percent) used sumatriptan too often (Ottervanger et al. 1996:353). Another study conducted in Denmark reported that the one percent and $10 \%$ heaviest users of sumatriptan were responsible for $20 \%$ and $60 \%$ of total consumption, respectively (Gaist et al. 1996:162). Limited information is furthermore available on the long-term effects of sumatriptan (Visser, De Vriend, Jaspers \& Ferrari, 1996:46). Little is known about whether headache relief after sumatriptan and the occurrence of headache recurrence and chest symptoms are attack-related effects (that is, may vary per attack within a patient) or are patient-related effects (that is, may vary between patients but are consistent effects within a patient over multiple attacks) (Visser et al. 1996:46).

Migraine affects primarily the economically active sector of the community. Pharmacists therefore have an important role to play in managing and counselling migraine sufferers. Furthermore, since the treatment of migraine is expensive, the impact that drugs for the treatment of migraine, with specific emphasis on sumatriptan and the other triptans, have on the quality of life of migraine sufferers should be measured in economic terms.

Studies on the pharmacoepidemiology of migraine can greatly enhance the understanding of this disease state in South Africa. It is recommended that further drug utilisation studies on the prescribing of the triptans be conducted as the newer triptans are introduced onto the South African market. Furthermore, qualitative studies where interviews are conducted with patients suffering from migraine can greatly enhance the understanding and treatment of patients with migraine.

\section{ACKNOWLEDGEMENTS}

- $\quad$ The financial assistance of the Medical Research Council (MRC) towards this research is hereby acknowledged. Opinions expressed in this paper and conclusions arrived at, are those of the authors and are not necessarily to be attributed to the Medical Research Council.

- The two organisations that provided the data for the study.

- Mrs Samantha Venter for assisting in proofreading the manuscript.

\section{REFERENCES}

ANATOMICAL THERAPEUTIC CHEMICAL (ATC) CLASSIFICATION INDEX WITH DEFINED DAILY DOSES (DDDs) January 1999: Oslo: WHO Collaborating Centre for Drug Statistics Methodology. GAIST, D;ANDERSEN, M;AARUP, A-L; HALLAS, J \& FRENG GRAM, L 1997: Use of sumatriptan in Denmark in 1994-5: An epidemiological analysis of nationwide prescription data. British Journal of Clinical Pharmacology, 43:429-433.

GAIST, D; HALLAS, J; SINDRUP, SH \& GRAM, LF 1996: Is overuse of sumatriptan a problem? - A population-based study. European 
Journal of Clinical Pharmacology, 50:161-165.

HALLAS, J \& NISSEN, A 1994: Individualized drug utilization statistics: analysing a population's drug use from the perspective of individual users. European Journal of Clinical Pharmacology, 47:367-372.

MeReC BULLETIN 1992: Oral sumatriptan. Liverpool: Medicines Resource Centre, 3(8):29-31.

MERCK MANUAL OF DIAGNOSIS AND THERAPY 1999: Beers, MH \& Berkow, R, eds; $17^{\text {th }}$ edition. New Jersey: Merck Research Laboratories.

MIMS - see MIMS Medical Specialities.

MIMS MEDICAL SPECIALITIES 1997: Snyman JR, Pope Al, eds Pretoria: Times Media, August, 37(8).

OTTERVANGER, JP; VALKENBURG, HA; GROBBEE, DE \& STRICKER BHCh 1996: Pattern of sumatriptan use and overuse in general practice. European Journal of Clinical Pharmacology, 50:353-355.

PORTA, M, HARTZEMA, AG \& TILSON, HH 1998: The contribution of epidemiology to the study of drug uses and effects. (In: Hartzema, AG; Porta, M \& Tilson, HH eds. 1998: Pharmacoepidemiology: An Introduction; third edition. Cincinnati: Harvey Whitney).

RASMUSSEN, BK; JENSEN, R \& OLESEN, J 1992: Impact of headache on sickness absence and utilisation of medical services: a Danish population study. Journal of Epidemiology and Community Health, 46:443-446.

RASMUSSEN, BK; JENSEN, R; SCHROLL, M \& OLESEN, J 1991: Epidemiology of headache in a general population - a prevalence study. Journal of Clinical Epidemiology, 44(11):1147-1157. SAMF - see South African Medicines Formulary. SCHOENEN, J; BULCKE, J; CAEKEBEKE, J; DEHAENE, I; DE KEYSER, J; HILDEBRAND, G; JOFFROY, A; LALOUX, P; LOUIS, P; MONSEU, G; PIERRE, P; VANDERLINDEN, C; SAUTOIS, D \& VANDENBERGHE, A 1994: Self-treatment of acute migraine with subcutaneous sumatriptan using an auto-injector device: Comparison with customary treatment in an open, longitudinal study. Cephalalgia, 14:55-63.

SMUTS, JA 2003: Migraine: diagnosis and current management options. South African Pharmaceutical Journal incorporating Pharmacy Management, 70(10):29-33.

SOUTH AFRICAN MEDICINES FORMULARY 1997: Gibbon, CJ \& Swanepoel, CR, eds; fourth edition Cape Town: Medical Association of South Africa, Publications Department.

TURNER, L 1996: The management of migraine headaches. PLUSfile, Module 4 as part of the PLUS Continuing Pharmacy Education Programme. Braamfontein: TPS Drug Information Centre, 1-16.

VAN SCHOOR, J 1999: Migraine - more than a headache. Pharmacy Management, 20(9):4-8.
VISSER, WH; DE VRIEND, RHM; JASPERS, NMWH \& FERRARI, MD 1996: Sumatriptan in clinical practice: A 2-year review of 453 migraine patients. Neurology, 47:46-51. 